\title{
Studies on Catecholamine Output in Urine Before and After Bilateral Adrenalectomy
}

\author{
Ken KAWAHARA \\ The Second Department of Surgery, Nagoya University, School of Medicine \\ (Director : Professor Dr. Hajime Imanaga)
}

Catecholamine, as well as adrenal cortical hormone, has been recently recognized as indispensable to maintain the homeostasis of the circulatory system. There are few reports about the relation between adrenal cortical hormone and catecholamine in bilateral adrenalectomized patient. In this paper, the urinary output of catecholamine before and after adrenalectomy was investigated and the effects of cortisone, ACTH, and DOCA on urinary catecholamine excretion were also studied.

The results were as follows:

1) Adrenaline excretion decreased one third or one fifth of normal value after the bilateral adrenalectomy, and, even three years after the operation, the excretion still remained at low level. It is noteworthy that the urinary excretion of adrenaline was always found after the operation in all cases, although the quantity was small. It might be supposed that the persistent adrenaline is derived from chromaffine cells other than adrenal medulla.

2) On the other hand, the excretion of noradrenaline was about twice as much of that before the bilateral adrenalectomy at one month after the operation, and it rose up to three or four times at three months after surgery. But this elevated value declined again to normal level in about six or twelve months later.

3) The urinary excretion of noradrenaline, that increased after the bilateral adrenalectomy, was significantly decreased by cortisone, whereas there was no change by DOCA. These findings suggest that the excretion of noradrenaline is mostly influenced by glucocorticoid rather than mineralocorticoid.

4) The blood pressure was labile immediately after the bilateral adrenalectomy, but stabilized four days after the operation by a proper supply of corticoids. Only nine of twenty four cases required noradrenaline in order to maintain normal blood pressure during the operation; none of the cases required it four days after the operation. The above results lead to the conclusion that the replacement therapy in adrenalectomized patients does not require catecholamine substitution.

5) The blood pressure fell markedly after the withdrawal of corticoid replacement therapy in bilateral adrenalectomized patients. It reterned to normal level by the administration of corticoids. Pressor effects of noradrenaline was slight in adrena- 
lectomized patients, whereas the effect was increased by the combined administration of noradrenaline and glucocorticoid. These facts suggest that the role of noradrenaline is synergistic with corticoids.

6) The response of blood pressure to subcutaneous administration of noradrenaline was depressed soon after the bilateral adrenalectomy but it returned gradually to normal. This may be one of the reasons why the urinary excretion of noradrenaline increased after the adrenalectomy.

(pp. 1327 1344) 


\title{
副腎全剔後の尿中 Catecholamine の推移
}

\author{
名古屋大学医学部今永外科 (指導 今永 一教授) \\ 河原健
}

（昭和39年 7 月 28 日受付）

\begin{tabular}{|c|c|}
\hline 目 & 次 \\
\hline 第 1 章 緒 論 & 笴 3 節 各種薬剂投与による尿中 Catech- \\
\hline 第 2 章 実験対象及び実験方法 & olamine 排泄量への影響 \\
\hline 第 1 節 実験対象 & 第 1 項 Cortisone 負荷による影響 \\
\hline 第 2 節 実験方法 & 第 2 項 ACTH 負荷による影響 \\
\hline 第 3 章 実験成績 & 第 3 項 DOCA 負荷による影響 \\
\hline $\begin{array}{c}\text { 第 } 1 \text { 節 副腎全剔例の尿中 Catecholamine } \\
\text { 排泄量 }\end{array}$ & 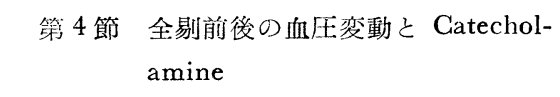 \\
\hline $\begin{array}{c}\text { 第 } 1 \text { 項 副腎全剔前後の尿中 Catechol- } \\
\text { amine 変動 }\end{array}$ & $\begin{array}{c}\text { 第 } 5 \text { 節 } \begin{array}{c}\text { 全剔患者の Adrenaline 及び N- } \\
\text { oradrenaline に対する感受性 }\end{array}\end{array}$ \\
\hline 第 2 項 副腎全剔前後の長期観察 & 第 4 章 総括及び考按 \\
\hline 第 2 節 副腎㖪質剔除例との比較 & 第 5 章 結 \\
\hline
\end{tabular}

第 1 章 緒

論

Adrenaline（A）及び Noradrenaline（NA）によつて代表される所謂 Catecholamine は副腎髄質ホル モンとして生体内分泌系に関与すると共に交感神経刺㦸伝導物質として生理的意義は大なるものがある。

NA は既に古く1904年に S. Stolz により合成され，1906年 Biberfeld 治力な Vasoconstrictor として 血圧上昇物質として臨床的利用を暗示し，1946年 Euler，P. Holtz が各殆んど同時に動物の体内に存在する事 を発見して以来急に注目の的となり，近年その代謝機序の解明と測定法の確立によりその研究は急激なる発 展を遂げた。 Gatecholamine の生合成については1947年 Gurin，Delluvaら ${ }^{1)}$ 亿始まる放射性同位元素を用い る Tracerexperiment によつてその生合成の経路は解明され，現在では Blaschko2) の示した経路 Phenylalanine $\rightarrow$ Tyrosine $\rightarrow$ Dopa $\rightarrow$ Dopamine $\rightarrow$ Noradrenaline $\rightarrow$ Adrenaline $の$ 順で生合成される事には疑問の余 地はない, 又, 代謝機序の研究は Armstrong ${ }^{3)} の$ Vanillyl mandelic acid の発見以来急に進展し Monoamine Oxidase による酸化的脱ア之ノ，Catechol-O-Methyl-Transferase による O-メチル化，硫酸抱 合，グルクロン酸抱合等の代謝機序がかなり明らかになつた。

一方その微量定量法の進歩も著しく古くは Bioassay による定量が行なわれていたが，アルカリ性溶液中 の Catecholamine の螢光反応を応用した螢光定量法が Pekkarinen ${ }^{4)}$ (1948年), Lund ${ }^{5)}(1950)$, Weil Malharbe \& Bone ${ }^{6)}$ (1953) 更には Euler \& Floding ${ }^{7}$ (1955) 等により改良され，最近 Goodall等 $\left.{ }^{8}\right)$ はイオン交換樹脂 カラムを用いた方法を報告し精製濃縮法, 分離法が進歩し定量法の感度が上昇して臨床的応用も近年著しく 盛んになつた.

Engel \& Euler ${ }^{9}$ (1950) が Pheochromacytoma の患者の尿中 NA を測定して以来多くの研究者により 手術, 発熱, 低血糖, 筋労作, 麻酥, 寒泠, 出血, 腰麻ショック, 高血圧やその他 種々の内分泌疾患の Catecholamine の動態が追求され最近では精神笂患との関連性も注目されて来た ${ }^{10) 11112) 1314) 15)}$. 
NA は Steroid Hormone と共に循環系の Homeostasis を維持するに必要欠くべからざるものとして今 日重要視されているが(14)，副腎全剔後の A，NA の動態を追求する事は娟質と Catecholamine との関係， 副腎皮質ホルモンと Catecholamine との関係或いは循環系に及ぼす影響を知る上に意義大なるものがある と考えられる。

而して副腎全剔後の Catecholamine の研究は非常に少い，幸，教室に於ては末期乳癌患者の治療の1つ として副腎卵巣全剔術を施行しているが筆者は全剔術前後の Catecholamine の動態を観察し，髄質剔除例 と比較しながう又 Cortisone, ACTH，DOGA 等の投与による尿中 Catecholamine の変動をしらへ， Catecholamine と皮質ホルモンとの関係，血圧との関係を追求せんとした。

\section{第 2 章 実験対象及び実験方法}

\section{第 1 節 実験対象}

当今永外科教室に於ける末期乳癌患者で両側副腎全剔術，両側卵巣全剔術を施行せる女子で (Hydrocortisone 20 ４0ing/day で維持）年令は34才より62才までの 25 例を選んだ.

対照として特発性脱疽にて両側副腎㖪質剔除術を施行せる 1 例を，又入院患者で安静臥位を保つた乳腺良 性腫瘍, 虫垂炎, 下腿骨骨折等の軽症者を選んだ。

\section{第 2 節 実験方法}

Catecholamine の測定法として初期は生物学的定量法が用いられていたが，手技感度の点でその誤差は 大きく殆んぞ用いられていない，しかるにアルカリ溶液中での Catecholamine の螢光反応を応用した微量 螢光定量法が研究改良されて ${ }^{5) 67) 88)}$ 今日では殆んぞ此の方法が用いられている.

著者は佐野氏法 ${ }^{16)}$ を用いた。それは Catecholamine をアルミナに吸着後弱酸にて溶出しその溶出液を Amberlite CG-50 カラムに通し，更に塩酸により溶出した Eluate に Trihydroxyindol 法 (THI 法) を 施行するものである。

THI 法では PH 3.5 で NA は殆んぞ酸化されずAのみ酸化され，PH 6.0 では A，NA 共に酸化され て Lutin となり螢光を発するものでありてれを利用して A, NA の分離定量を行うものである.

〔試薬及び操作〕

尿はあらかじめ少量の濃硫酸及び EDTA $1 \mathrm{~g}$ を入れた蓄尿瓶に泠蔵庫中にて採取した。尿はすべて24時 間尿で安静臥位時のものである.

24時間尿中の100ccを取り活性アルミナ $2.5 \mathrm{gr}^{16)} \mathrm{EDTA} 1 \mathrm{gr}$, 更に指示薬として $2 \%$ BTB アルコール溶 液数滴を加え充分㨘汼しつつ $20 \%$ 苛性ソーダを滴下し青変後 $5 \%$ 苛性ソーダを加え Test Paper CR にて可

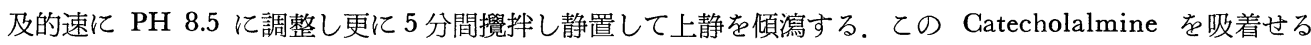
アルミナを No. 3 のグラスフイルター上に移す。 $0.2 \mathrm{~N}$ 醋酸 $5 \mathrm{cc}$ をてれに注ぎ 3 分間㩭拌後小試験管内に溶 出し更に $4 \mathrm{cc}$ を用いて同様に溶出する。.とのアルミナの醋酸溶出液を 1 分間 1500 回転で 5 分間遠沈しその上 清に重炭酸ソーダを加えて正確に PH 6.5 亿調整，水を加えて $10 \mathrm{cc}$ とした後，あらかじめ調整した Amberlite CG 50カラム ${ }^{16)}$ 亿通す．続いて $10 \mathrm{cc}$ の PH 6.5 の 0.2M 燐酸ナトリウム緩衝液で洗う。この Effluent は Dopa，酸性及び中性 Catechol 体の測定に用いる. 次いで N-塩酸 $15 \mathrm{cc}$ を通しての Eluate は A，NA 及び DA の測定に使用する。

〔螢光定量〕

尿抽出物に依る螢光阻害を避けるために内部規準法を採用した。

Table 1 の如く上記 Effluent から Blank, Sample, Sample+Dopa 0.2 $\mu \mathrm{g}$ を取り Sample 及び Sample + Dopa 亿各 $0.5 \%$ 硫酸覀鉛 $0.1 \mathrm{cc}, 0.25 \%$ フエリシャン化カリ $0.1 \mathrm{cc}$ を加えて酸化させ 5 分後にアルカリ 性アスコルビン酸（2\%アスコルビン酸と $20 \% \mathrm{NaOH}$ を：9亿混合） $1 \mathrm{cc}$ 加え酸化反応を停止せしめ ての螢光を測定する.

Eluate からも Blank, Sample, Sample + A $0.2 \mu \mathrm{g}$, 又は Sample + NA $0.2 \mu \mathrm{g}$ の内部規準液を作り各醋酸 第40巻 第 10 号 
Table 1. THI-Method

1) Reaction systems in the determination of DOPA

\begin{tabular}{|c|c|c|c|c|c|c|c|}
\hline & Ef & $\begin{array}{l}\text { Distilled } \\
\text { Water }\end{array}$ & $\begin{array}{l}\text { DOPA } \\
1 \mu \mathrm{g} / \mathrm{cc}\end{array}$ & $\begin{array}{c}0.5 \% \\
\mathrm{ZnSO}_{4}\end{array}$ & $\begin{array}{c}0.25 \% \\
\mathrm{~K}_{3} \mathrm{Fe}(\mathrm{CN})_{6}\end{array}$ & & $\begin{array}{l}20 \% \mathrm{NaOH}+ \\
2 \% \text { Ascorbic } \\
\text { Acid }\end{array}$ \\
\hline Blank & 2.0 & 0.4 & & & & 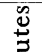 & 1.0 \\
\hline Sample & 2.0 & 0.2 & & 0.1 & 0.1 &. & 1.0 \\
\hline Sample+DOPA & 2.0 & & 0.2 & 0.1 & 0.1 & ח & 1.0 \\
\hline
\end{tabular}

2) Reaction systems in the determination of adrenaline and noradrenaline

\begin{tabular}{|c|c|c|c|c|c|c|c|c|c|c|}
\hline & \multirow{2}{*}{ E1 } & \multicolumn{2}{|c|}{$\begin{array}{l}\text { 1M Acetate } \\
\text { Buffer }\end{array}$} & \multirow{2}{*}{$\begin{array}{c}\text { Distilled } \\
\text { Water }\end{array}$} & \multicolumn{2}{|c|}{$\mathrm{A}$ or NA $1 \mu \mathrm{g} / \mathrm{cc}$} & \multirow{2}{*}{$\begin{array}{l}0.5 \% \\
\mathrm{ZnSO}_{4}\end{array}$} & \multirow{2}{*}{$\begin{array}{r}0.25 \% \\
\mathrm{~K}_{3} \mathrm{Fe} \\
(\mathrm{GN})_{6} \\
\end{array}$} & \multirow{2}{*}{\multicolumn{2}{|c|}{$\begin{array}{l}20 \% \mathrm{NaOH} \\
\quad+ \\
2 \% \text { Ascorbic } \\
\text { Acid }\end{array}$}} \\
\hline & & pH 3.5 & $\mathrm{pH} 6.0$ & & A & NA & & & & \\
\hline Blank & 1.5 & 1.0 & & 0.4 & & & & & & 1.0 \\
\hline Blank & 1.5 & & 1.0 & 0.4 & & & & & & 1.0 \\
\hline Sample & 1.5 & 1.0 & & 0.2 & & & 0.1 & 0.1 & is & 1.0 \\
\hline Sample & 1.5 & & 1.0 & 0.2 & & & 0.1 & 0.1 & $\stackrel{\underline{J}}{\Xi}$ & 1.0 \\
\hline Sample + NA & 1.5 & 1.0 & & & & 0.2 & 0.1 & 0.1 & $\overrightarrow{\mathrm{g}}$ & 1.0 \\
\hline Sample + NA & 1.5 & & 1.0 & & & 0.2 & 0.1 & 0.1 & in & 1.0 \\
\hline Sample + A & 1.5 & 1.0 & & & 0.2 & & 0.1 & 0.1 & & 1.0 \\
\hline Sample + A & 1.5 & & 1.0 & & 0.2 & & 0.1 & 0.1 & & 1.0 \\
\hline
\end{tabular}

緩衝液にて PH 3.5 及び PH 6.0 の 2 群に分け Effluent と同様酸化反応による螢光を測定する.

測定は八木式微量螢光光度計を用い，一次フィルターに $\mathrm{UVV}_{1}$, 二次フイルターに $\mathrm{F}_{1} \mathrm{~B}_{2}, \mathrm{UVO}_{2}$ を用い た。 なお酸化反応は室温によりかなり影響されるため常に一定温度内にて行うよう努めた。尚尿中 Catecholamine には遊離型と結合型があるが加水分解, 䤉素的水解等になほ問題があり誤㐙を生じ易いためててで 測定した值はすべて遊離型のものである.

又，17KS は Drekter 変法，17OHCS は Reddy-Jenkins-Thorn 変法により測定した。

\section{第 3 章 実 験 成 績}

\section{第 1 節＼cjkstart副腎全剔例の尿中 Catecholamine について}

第 1 項 副腎全剔前後の尿中 Catecholamine の変動

副腎全剔前及び後の尿中 Catecholamine を12例について測定し比較した。 その結果は Table 2 の如く である.

A は Fig. 1 の如く全例に於て全剔後排泄量は減少し，術前の $1 / 3$ から少い例では $1 / 5$ 亿なつており術 後 3 ケ月後にも $0.37 \mu \mathrm{g} / \mathrm{day}$ (術前 $2.46 \mu \mathrm{g} / \mathrm{day}$ ), $0.31 \mu \mathrm{g} / \mathrm{day}$ (術前 $1.85 \mu \mathrm{g} / \mathrm{day}$ ), $1.74 \mu \mathrm{g} / \mathrm{day}$ (術前 $6.8 \mu \mathrm{g} /$ day), $0.66 \mu \mathrm{g} / \mathrm{day}$ （術前 $2.57 \mu \mathrm{g} / \mathrm{day}$ ) と何れも減少したままである.

しかしこてで興味があるのは全剔後の尿中 $\mathrm{A}$ は減少はするが0にならない事であり全剔後にもなお排泄さ れるAは副腎髄質以外に由来するものと考元られる。

次に NA はFig. 2 の如く全剔後A と反対に術前值よりむしろ増加の傾向が見られた. 1 ケ月後に測定 した例では術前の約 2 倍前後の增加が見られ，3ケ月後では 3 倍から 4 倍，中には10倍近くも増加した例が あり，術後 3 ケ月に於てもなお高值を示し且つ 1 ケ月後よりもむしろ排泄量が多くなつている.

又 A と NA の比 (NA/A) を比較して見ると Table 2 の如く術前平均 3.77 であつたものが術後平均 38.49と約10倍近くになつており，てれはAの減少と相まつて NA の増加によりかかる高值を示したもので 
Table 2. Catecholamine output in urine before and after bilateral adrenalectomy

\begin{tabular}{c|c|c|c|c|c|c|c}
\hline \multirow{2}{*}{$\begin{array}{c}\text { Name of } \begin{array}{c}\text { the } \\
\text { patient }\end{array} \\
\text { Age }\end{array}$} & \multicolumn{2}{|c|}{ A $\mu \mathrm{g}$ /day } & \multicolumn{2}{|c|}{ NA $\mu \mathrm{g} /$ day } & \multicolumn{2}{c}{ NA/A } \\
\cline { 2 - 8 } S.N. & 37 & 2.80 & 0.82 & 10.97 & 15.84 & 3.91 & 19.31 \\
A.M. & 34 & 2.46 & 0.37 & 7.68 & 22.86 & 3.12 & 61.78 \\
S.M. & 48 & 2.57 & 0.66 & 8.32 & 27.95 & 3.23 & 42.34 \\
A.K. & 37 & 1.85 & 0.31 & 8.94 & 17.24 & 4.83 & 55.61 \\
T.T. & 43 & 4.61 & 1.14 & 4.18 & 30.61 & 0.90 & 26.85 \\
Y.N. & 42 & 3.30 & 1.26 & 12.06 & 15.37 & 3.09 & 12.19 \\
T.O. & 35 & 3.21 & 1.00 & 20.14 & 47.55 & 6.27 & 47.55 \\
K.K. & 58 & 6.80 & 1.74 & 4.46 & 54.56 & 0.65 & 31.35 \\
T.H. & 52 & 2.35 & 0.32 & 7.24 & 12.73 & 3.08 & 39.78 \\
T.K. & 42 & 1.55 & 0.17 & 5.74 & 12.87 & 3.67 & 75.70 \\
Y.H. & 43 & 1.61 & 0.58 & 6.85 & 10.25 & 4.25 & 17.67 \\
M.T. & 40 & 2.58 & 1.11 & 5.73 & 14.36 & 2.22 & 12.93 \\
\hline
\end{tabular}

Fig. 1. Changes in adrenaline output in urine before and after bilateral adrenalectomy

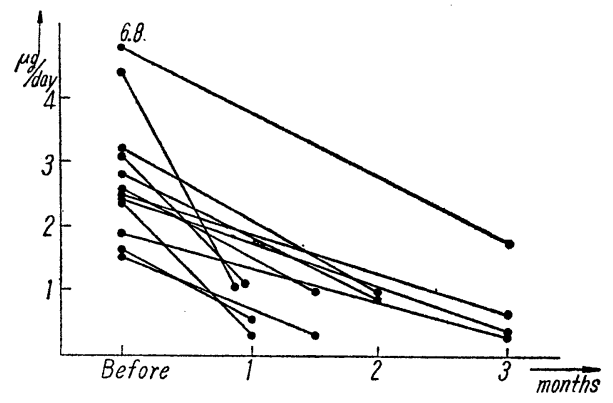

Fig. 2. Changes in noradrenaline output in urine before and after bilateral adrenalectomy

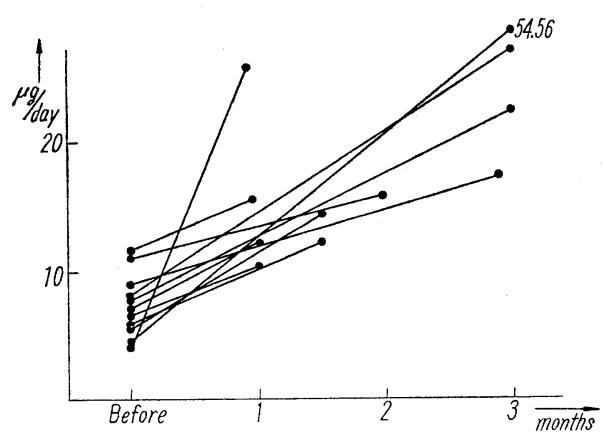

ある事が理解される。

第 2 項 副腎全剔前後の長期観察

前項に於て全剔前後の尿中 Catecholamine を比較して, 全剔後Aは減少し NA は増加する事を知つた が，更に長期にわたり観察し尿中 Catecholamine が如何なる経過を取つて変動するかる検討した。 その結 果は Table 3 の如くである。

症例 1. 58才，女，Fig. 3. 術前Aは $6.8 \mu \mathrm{g} / \mathrm{day}$ であるが術後第 1 日目に $6.44 \mu \mathrm{g} / \mathrm{day}$ 第 4 日目に 1.20 $\mu \mathrm{g} / \mathrm{day}$ と減少し，その後多少の増減はあるが術前值より低值のままで術後約 1 年後に於ても $0.96 \mu \mathrm{g} / \mathrm{day}$ と増加していない.

一方 NA は術前 $4.46 \mu \mathrm{g} / \mathrm{day}$ であるが術後第 1 日目 $3.95 \mu \mathrm{g} / \mathrm{day}$ と一時低下しその後 増加し始め術後 14 日目に $12.74 \mu \mathrm{g} / \mathrm{day}, 90$ 日後には $54.56 \mu \mathrm{g} /$ day と最高值に達した。しかるに術後120日後には $30.92 \mu \mathrm{g} / \mathrm{day}$ と減少し, 約 1 年後には $15.06 \mu \mathrm{g} / \mathrm{day}$ となり術前值に近い值に戾つた.

症例 2. 35才，女，Fig. 4. 術前 A 排泄量は $3.21 \mu \mathrm{g} / \mathrm{day}$ であつたものが術後第 1 日目に $0.53 \mu \mathrm{g} / \mathrm{day}$ と

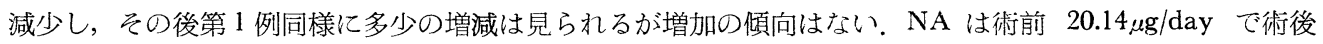


Table 3. Gatecholamine output in urine before and after bilateral adrenalectomy ( $\mu \mathrm{g} / \mathrm{day}$ ) Case 1, K.K. 58 F Case 2, T.O. $35 \mathrm{~F}$ Case 3, Y.N. 42 F Case 4, T.T. $43 \mathrm{~F}$

\begin{tabular}{c|r|r|r|r|r|r|r|r|r|r|r|r|r|r|r|r|r|r|r}
\hline Days & D & A & N A & Days & D & A & N A & Days & D & A & N A & Days & D & A & N A \\
\hline \hline Before & 6.66 & 6.80 & 4.46 & Before & 11.92 & 3.21 & 20.14 & Before & 5.44 & 3.30 & 12.06 & Before & 7.79 & 4.61 & 4.18 \\
1 & 4.78 & 6.44 & 3.95 & 1 & 6.87 & 0.53 & 3.24 & 1 & 5.75 & 2.34 & 11.34 & 1 & 10.66 & 3.74 & 5.58 \\
4 & 12.65 & 1.20 & 6.65 & 7 & 8.00 & 1.21 & 3.57 & 3 & 8.72 & 1.42 & 8.12 & 3 & 15.37 & 0.00 & 31.13 \\
7 & 23.25 & 1.93 & 3.41 & 17 & 11.87 & 5.79 & 2.94 & 7 & 6.18 & 1.35 & 10.24 & 9 & 11.45 & 1.28 & 12.67 \\
14 & 12.70 & 1.34 & 12.74 & 27 & 9.21 & 1.33 & 4.96 & 14 & 17.18 & 1.50 & 13.53 & 14 & 11.76 & 0.95 & 79.38 \\
28 & 33.66 & 2.85 & 20.30 & 37 & 34.65 & 2.36 & 40.21 & 28 & 11.63 & 1.26 & 15.37 & 21 & 16.21 & 1.14 & 30.61 \\
54 & 98.00 & 4.31 & 22.70 & 47 & 44.08 & 1.83 & 53.59 & & & & & & & & \\
90 & 47.73 & 1.74 & 54.56 & 60 & 36.51 & 1.00 & 47.55 & & & & & & & & \\
120 & 18.08 & 2.03 & 30.92 & 151 & 5.32 & 0.00 & 25.92 & & & & & & & & \\
200 & 4.79 & 0.60 & 16.62 & & & & & & & & & & & & \\
372 & 5.79 & 0.96 & 15.06 & & & & & & & & & & & \\
\hline
\end{tabular}

Fig. 3. Ghanges in catecholamine output in urine before and after bilateral adrenalectomy

Case 1, K.K. 58yrs F

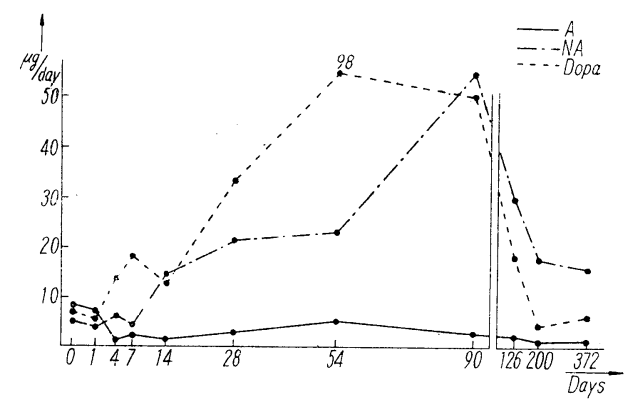

Fig. 4. Changes in catecholamine output in urine before and after bilateral adrenalectomy

Case 2, T.O. 35yrs F

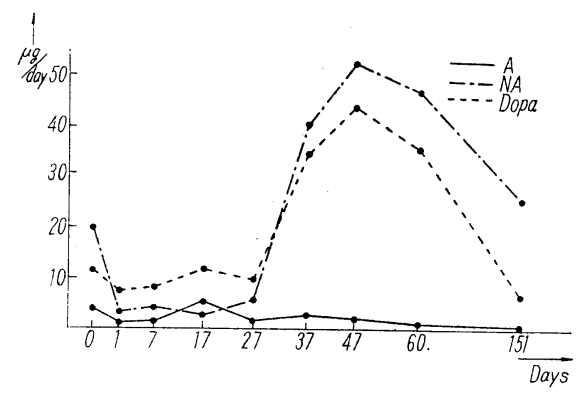

第 1 日目 $3.24 \mu \mathrm{g} / \mathrm{day}$ と一時減少するがやがて第 1 例同様増加し始め47日後には $53.59 \mu \mathrm{g} / \mathrm{day}$ となり術前 の 2 倍以上に増加し以後减少して約 5 ケ月後には $25.92 \mu \mathrm{g} / \mathrm{day} の$ 値を示した.

症例 3 ，42才，女，術後約 1 ケ月で死亡した症例でAはやはり術後減少したままであるが NA には増加 の傾向が見られる。

症例 4.43才，女，A は術後減少し逆に NA は増加しており以上 3 例と同様の傾向を示している.なお Catecholamine の前駆物質たる DOPA の尿中存在については種々議論されている所であるが本測定法に より測定し得た DOPA も以上 4 例に見られる如く術後 NA と殆んど同様の増減経過を取つた.

\section{第 2 節 髄質剔除例との比較}

全剔後数倍も尿中 NA 排泄量が増加する原因として手術による stress，A 分泌減少，皮質ホルモン欠落 による影響，分泌中枢の問題等種々の Factor が考えられる.

そこで先ず髄質のみの剔除による尿中 Catecholamine の変動を観察し全剔例と比較してみた.

Table 4，Fig. 5 は特発性脱疽で髄質剔除を行つた症例の術前後の尿中 Catecholamine の变動を示した

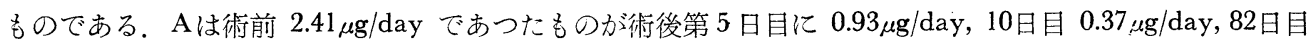
にも $0.70 \mu \mathrm{g} / \mathrm{day}$ で術前の約 $1 / 3$ に最高 $1 / 7$ にも減少した。 又82日後においても減少したままで増加の傾 向はなく，又排泄量が０になる事もなく副腎全剔例と比較して全く同様の経過を取つている事がわかる，術 
Table 4. Catecholamine output in urine before and after bilateral adrenomedullectomy ( $\mu \mathrm{g} / \mathrm{day})$

\begin{tabular}{c|c|c|c|c|c}
\hline \hline Days & $\mathrm{D}$ & $\mathrm{A}$ & $\mathrm{N} \mathrm{A}$ & 17-OHCS* & 17-KS* \\
\hline Before & 8.94 & 2.41 & 15.35 & 14.6 & 1.0 \\
2 & 1.73 & 1.40 & 13.58 & 29.2 & 0.1 \\
5 & 9.27 & 0.93 & 14.08 & 31.8 & 1.4 \\
10 & 8.38 & 0.37 & 17.21 & 5.9 & 4.5 \\
15 & 7.13 & 0.81 & 29.01 & 2.9 & 1.1 \\
22 & 9.27 & 1.58 & 21.87 & & 0.1 \\
34 & 10.27 & 0.83 & 17.96 & 4.9 & 2.9 \\
82 & 9.25 & 0.70 & 6.21 & 4.5 & 3.0 \\
\hline
\end{tabular}

$* \mathrm{mg} / \mathrm{day}$

後なお排泄される $\mathrm{A}$ は髄質以外に由来するもので あろう。

次に NA は術前 $15.35 \mu \mathrm{g} / \mathrm{day}$ であつたものが 術後第 5 日目には $14.08 \mu \mathrm{g} /$ day と僅に減少した が，10日後には $17.21 \mu \mathrm{g} /$ day と逆に増加し，15 日後には $29.01 \mu \mathrm{g} / \mathrm{day}$ と最高值を示し以後减少

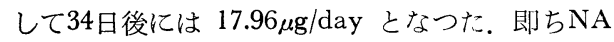
は術後一時減少するがその後増加し約 2 週間後に 最高值を示し約 1 ケ月後には減少して術前のレベ ルに戾つた。乙れは副腎全剔例と同様な pattern を取つて増減しているが全剔例では術後の最高值 が $50 \mu \mathrm{g} /$ day 前後で，多いものでは $80 \mu \mathrm{g} /$ day に も達している点, 又髄質剔除例では約1ケ月後には

既に術前值のレベルに戾つているが全剔例では更に長期間にわたり高值を持続しその後始めて術前值のレベ ルに減少する点に相違が認められた。

なお尿中 17-OHCS, 17KS は Table 4 の如くで一般の手術侵襲時と同様の経過 を取つており皮質不全 は見られなかつた。即ち髄質剔除術に際し起る皮質損傷による副腎不全は認められない。

\section{第 3 節 各種薬剂投与による尿中 Catecholamine 排泄量への影響}

全剔後尿中 NA が術前より数倍も増加する原因として手術時の stress やAの分泌減少を代償するために

Table 5. Catecholamine output in urine after the administration of cortisone in normal subjects ( $\mu \mathrm{g} / \mathrm{day})$

\begin{tabular}{|c|c|c|c|c|c|c|c|c|c|c|}
\hline \multirow[t]{2}{*}{ Case } & \multicolumn{2}{|c|}{1} & \multicolumn{2}{|c|}{2} & \multicolumn{2}{|c|}{3} & \multicolumn{2}{|c|}{4} & \multicolumn{2}{|c|}{5} \\
\hline & A & $\mathrm{NA}$ & A & $\mathrm{NA}$ & A & NA & A & NA & A & NA \\
\hline Before & 1.85 & 8.94 & 0.91 & 4.17 & 1.71 & 16.01 & 0.65 & 7.46 & 1.77 & 5.52 \\
\hline 1 & 1.21 & 10.86 & 1.21 & 6.29 & 1.26 & 13.89 & 0.74 & 6.77 & 0.91 & 3.60 \\
\hline 2 & 2.07 & 12.95 & 0.80 & 4.70 & 0.87 & 9.16 & 0.65 & 5.81 & 1.33 & 5.01 \\
\hline 3 & 2.52 & 19.40 & 1.59 & 8.57 & 2.63 & 20.50 & & & 3.31 & 6.20 \\
\hline
\end{tabular}


一過性に NA の分泌六進が起る事も予想される。 しかし前節に述べた如く髄質剔除例では最高值が 全剔例より低い事，1 ケ月後には既に術前值のレ ベルに戾つている事など全剔後かなり長期間にわ たりしかも高值を持続する事実と異なりてれのみ で説明できない，髄質のみの剔除例と副腎全剔例 （皮質髄質全剔）とを比較した時，術後の副腎皮 質ホルモン供給の有無が原因とも考劣られ,

Cortisone; ACTH, DOCA の負荷を行い負荷前 後の尿中 NA を測定し比較検討した。

なお検查中は安静を保つた。

第 1 項 Cortisone 負荷による影響

Cortisone $200 \mathrm{mg}$ を朝夕 2 回に分けて経口投与して投与前及び第 1 日，第 2 日，第 3 日目の尿中 NA を 測定し比較した.

\section{(1) 正常例}

Table 5, Fig. 6 の如く5 例中 2 例は投与後 NA は僅に増加し減少傾向は見られなかつた. 他の 3 例は 投与後第 1 日目に平均 $1.57 \mu \mathrm{g}$ の減少があつたが，第 3 日目には何れも投与前の值近く戻つた。なお 著明な変化は見られなかつた，即ち正常例では投与後 NA が増加するもの，減少するもの，相半ばして一 定の傾向はなかつた.

\section{(2) 全剔例}

7 例につき測定した結果は Table 6, Fig. 7 の如くであつた. 7 例中 1 例を除いて投与後に NA は著明 に減少した。投与後第 1 日目には平均 $3.26 \mu \mathrm{g}$ 減少し正常例と比較すると約 3 倍多く, 第 2 日目には平均 $6.10 \mu \mathrm{g}$ と第 1 日目より約 2 倍の減少を見た.

Cortisone を投与して24時間以後にその効果がもつとも強く現われる様に思われた.

例外として第 7 例は術後 3 年を経過したもので投与前の NA は $7.86 \mu \mathrm{g} / \mathrm{day}$ で既に正常值に戾つた時期 にあり従つて投与後にも $8.64 \mu \mathrm{g} / \mathrm{day}, 7.39 \mu \mathrm{g} / \mathrm{day}$ で正常例と同様殆んど変化を示さなかつた.

これに反して投与前 NA の排泄量の多い例では Table 6 の如く投与前 $27.95 \mu \mathrm{g} / \mathrm{day}$ が第 1 日目 23.57 $\mu \mathrm{g} / \mathrm{day}$ 第 2 日目には $16.15 \mu \mathrm{g} / \mathrm{day}$ となり強く減少したが，比較的排泄量の少い例では投与前 $17.24 \mu \mathrm{g} / \mathrm{day}$ ， 第1日 $15.04 \mu \mathrm{g} / \mathrm{day}$, 第 2 日 $16.33 \mu \mathrm{g} / \mathrm{day}$ で前者に比して Cortisone 投与の影響が弱い傾向が見られた.

又, Cortisone $50 \mathrm{mg}$ を連日投与し 2 週間後に測定した所 Fig. 8 の如く投与前 $7.56 \mu \mathrm{g} / \mathrm{day}$ であつたも のが $2.50 \mu \mathrm{g} /$ day となりやはり同様減少した.

Table 6. Catecholamine output in urine after the administration of cortisone in bilateral adrenalectomized patients $(\mu \mathrm{g} / \mathrm{day})$

\begin{tabular}{|c|c|c|c|c|c|c|c|c|c|c|c|c|c|c|}
\hline Case & \multicolumn{2}{|c|}{1} & \multicolumn{2}{|c|}{2} & \multicolumn{2}{|c|}{3} & \multicolumn{2}{|c|}{4} & \multicolumn{2}{|c|}{5} & \multicolumn{2}{|c|}{6} & \multicolumn{2}{|c|}{7} \\
\hline & A & $\mathrm{NA}$ & A & NA & A & NA & A & NA & A & NA & A & NA & A & NA \\
\hline Before & 0.31 & 17.24 & 0.66 & 27.95 & 0.97 & 10.24 & 0.45 & 17.29 & 0.17 & 12.87 & 1.11 & 14.36 & 0.61 & 7.86 \\
\hline 1 & 0.65 & 15.04 & 1.11 & 23.57 & 0.39 & 7.00 & 0.71 & 14.16 & 0.96 & 11.85 & 1.07 & 8.75 & 0.09 & 8.64 \\
\hline 2 & 0.51 & 16.33 & 0.16 & 16.15 & 0.41 & 6.48 & 0.47 & 7.30 & 0.68 & 8.98 & 2.20 & 8.09 & 0.71 & 7.39 \\
\hline 3 & 0.44 & 16.36 & 0.44 & 31.04 & 0.51 & 3.75 & & & 1.12 & 7.74 & 0.52 & 11.59 & 0.32 & 7.54 \\
\hline
\end{tabular}


Fig. 7. Changes in urinary noradrenaline after the administration of cortisone in bilateral adrenalectomized patients

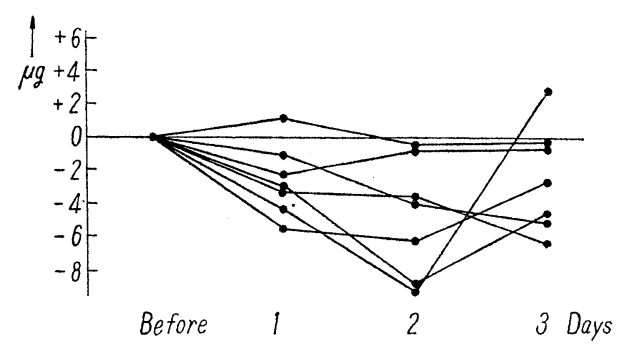

Fig. 8. Relationship between the doses of cortisone and urinary catecholamine in bilateral adrenalectomized patient

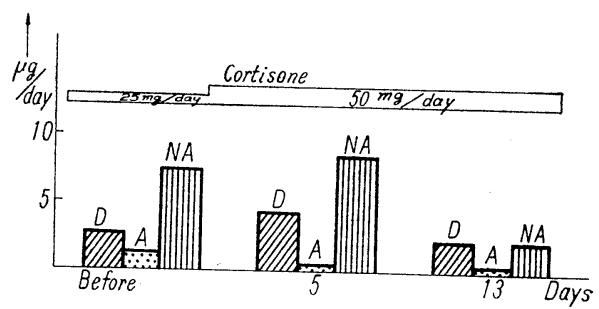

第 2 項 ACTH 負荷による影響

ACTH 負荷により皮質ホルモンの release を促進させてそれによる尿中 NA の变動を全剔前, 全剔後, 髄質剔除例について検討した。

ACTH Depot 40I.U. を 3 日連続投与し投与前後 5 日間の尿中 A，NA を連続測定した。

(1) 全剔前

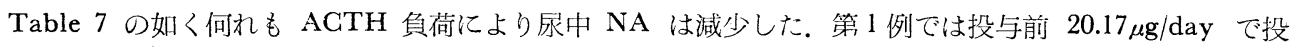

Table 7. Catecholamine output in urine after the administration of ACTH before bilateral adrenalectomy $(\mu \mathrm{g} /$ day $)$

\begin{tabular}{c|r|r|r|r|r|r|r|r|r|r|r|r}
\hline Case & \multicolumn{2}{|c|}{1} & \multicolumn{2}{|c|}{2} & \multicolumn{2}{|c|}{3} & \multicolumn{2}{c}{4} \\
\hline \hline & A & N A & A & N A & A & N A & A & N A & 17* & OHCS & 17K S* \\
\hline Days & & & & & & & & \\
\hline \hline Before & 3.73 & 20.17 & 1.80 & 15.31 & 2.43 & 25.27 & 1.61 & 6.85 & 9.7 & 0.9 \\
1 & 3.65 & 24.90 & 1.97 & 10.03 & 1.89 & 25.89 & 2.00 & 5.48 & 14.7 & 1.1 \\
2 & 2.70 & 18.73 & 1.95 & 9.92 & 2.10 & 21.10 & 1.49 & 5.06 & 7.6 & 0.8 \\
3 & 3.44 & 13.06 & 2.60 & 10.41 & 1.99 & 26.27 & 1.08 & 4.02 & 10.8 & 1.6 \\
4 & 3.99 & 22.61 & 1.30 & 14.51 & & & 2.46 & 7.74 & 22.9 & 1.3 \\
\hline
\end{tabular}

$* \mathrm{mg} / \mathrm{day}$

与後第 1 日目には $24.90 \mu \mathrm{g} / \mathrm{day}$ とやや増加したが第 2 日目には $18.73 \mu \mathrm{g} / \mathrm{day}$ と減少，第 3 日目には 13.06 $\mu \mathrm{g} / \mathrm{day}$ と投与前より $7.17 \mu \mathrm{g}$ の減少があつた.

第 2 例では $15.31 \mu \mathrm{g} / \mathrm{day}$ であつたものが第 1 日目には $10.03 \mu \mathrm{g} / \mathrm{day}$ と減少，更に第 2 日目には $9.92 \mu \mathrm{g} /$ day と投与前より $5.39 \mu \mathrm{g}$ 減少し，第 3 例では第 2 日目に強く減少し，第 4 例では投与前 $6.85 \mu \mathrm{g} / \mathrm{day}$ 第 3 日目には $4.02 \mu \mathrm{g} / \mathrm{day}$ とな $2.83 \mu \mathrm{g}$ に減少した。

一方A 殆んど変化なく ACTH による影響は考えられない. 又尿中 17-OHCS は増加し皮質は ACTH に反応した事を示している.

(2) 全剔後

全剔例では Table 8 の如く NA は ACTH を負荷しても投与前值と殆んど同じで著明な変動を示さな かつたＡも減少したままで変化はなかつた，勿論尿中 17-OHCS にも変動なく皮質性の反応がない事がわ かる.

(3) 副腎髄質剔除例

Table 9 の如く投与前 $17.96 \mu \mathrm{g} / \mathrm{day}$ であつたものが第 1 日目 $12.78 \mu \mathrm{g} / \mathrm{day}$ ，第 2 日目には $12.16 \mu \mathrm{g} / \mathrm{day}$ 第 40 巻 第 10 号 
Table 8. Catecholamine output in urine after the administration of ACTH in bilateral adrenalectomized patients ( $\mu \mathrm{g} / \mathrm{day})$

\begin{tabular}{|c|c|c|c|c|c|c|c|c|}
\hline Case & \multicolumn{2}{|c|}{1} & \multicolumn{2}{|c|}{2} & \multicolumn{4}{|c|}{3} \\
\hline Days & A & NA & A & NA & A & NA & $\begin{array}{c}17 * \\
\text { OHCS }\end{array}$ & $17 \mathrm{~K} \mathrm{~S} *$ \\
\hline Before & 0.82 & 10.00 & 0.37 & 22.86 & 0.84 & 15.84 & 18.1 & 0.8 \\
\hline 1 & 1.10 & 10.58 & 0.78 & 21.11 & 1.11 & 18.54 & & 0.3 \\
\hline 2 & 0.54 & 10.92 & 0.40 & 23.57 & 1.54 & 14.48 & 17.6 & 0.6 \\
\hline 3 & 0.37 & 10.32 & 0.60 & 21.08 & 2.57 & 13.91 & 19.0 & 0.0 \\
\hline 4 & 0.58 & 10.25 & 0.36 & 24.82 & 0.68 & 16.29 & & 0.8 \\
\hline
\end{tabular}

Table 9. Catecholamine output in urine after the administration of ACTH in bilateral adrenomedullectomized patient $(\mu \mathrm{g} /$ day $)$

\begin{tabular}{c|r|r|r|r}
\hline \hline Days & A & N A & $\begin{array}{c}17 * \\
\text { OHCS }\end{array}$ & 17 K S * \\
\hline \hline Before & 0.83 & 17.96 & 4.9 & 2.9 \\
1 & 0.88 & 12.78 & 6.3 & 3.6 \\
2 & 0.23 & 12.16 & 10.2 & 3.7 \\
3 & 0.49 & 16.79 & 15.3 & 4.8 \\
4 & 0.75 & 13.18 & & 4.6 \\
\hline
\end{tabular}

Fig. 9. Changes in urinary noradrenaline after the administration of ACTH

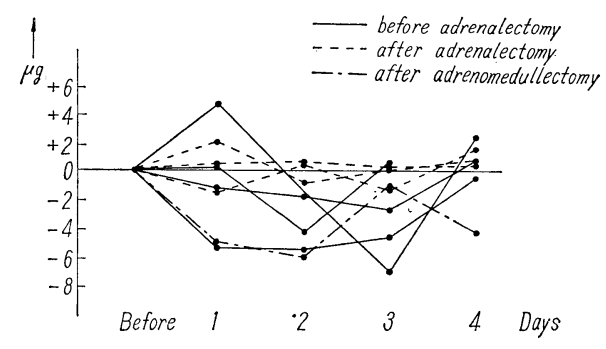

となり全剔前と同様著明に ACTH に反応した。 又Aは術後の低值のままで ACTH 投与による影響は何 ら受けなかつた，尿中 17OHCS は増加し皮質性の反応がある事を示している.

なお Fig. 9 は以上 3 群の ACTH 負荷後に於ける尿中 NA の増減を示したものである.

\section{第 3 項 DOGA 負荷による影響}

副腎皮質ホルモンは Glucocorticoid と Mineralocorticoid に分けられており，前項では Cortisone 及 び ACTH 負荷により Glucocorticoid と Catecholamine との関係について検討したが本項では Mineralocorticoid との関係を追求した.

Table 10. Catecholamine output in urine after the administration of DOCA before bilateral adrenalectomy ( $\mu \mathrm{g} / \mathrm{day})$

\begin{tabular}{|c|c|c|c|c|c|c|c|c|}
\hline Case & \multicolumn{2}{|c|}{1} & \multicolumn{2}{|c|}{2} & \multicolumn{2}{|c|}{3} & \multicolumn{2}{|c|}{4} \\
\hline Days & A & NA & $\mathrm{A}$ & $\mathrm{NA}$ & $\mathrm{A}$ & $\mathrm{NA}$ & $\mathrm{A}$ & NA \\
\hline Before & 1.48 & 22.48 & 1.71 & 24.23 & 3.99 & 22.61 & 2.02 & 22.23 \\
\hline 1 & 1.37 & 22.08 & 1.61 & 24.24 & 4.21 & 17.66 & 2.91 & 25.55 \\
\hline 2 & 1.35 & 21.90 & 1.16 & 25.55 & 1.68 & 13.22 & 2.82 & 30.93 \\
\hline 3 & 1.70 & 28.56 & 0.93 & 22.68 & 4.39 & 29.22 & 3.12 & 25.62 \\
\hline 4 & 1.17 & 12.72 & 1.64 & 13.73 & & & & \\
\hline
\end{tabular}


全剔前後について DOGA $5 \mathrm{mg}$ 又は $10 \mathrm{mg}$ 連続皮下注射を行い尿中 Gatecholamine の変動を観察した。 (1) 全剔前 (Table 10)

第1例は DOCA $5 \mathrm{mg}$ を 4 日連続投与したものである。投与後第1 日目，第 2 日目には殆んぞ NA の変化はないが第 3 日目に僅に増加し第 4 日目には $12.72 \mu \mathrm{g} / \mathrm{day}$ となり投与前より約 $10 \mu \mathrm{g}$ の減少を見た。 Aには殆んぞ変化は見られなかつた。第 2 例は DOCA $10 \mathrm{mg}$ を朝夕 2 回に分けて 4 日連続投与したもので 投与前値 $24.23 \mu \mathrm{g} / \mathrm{day}$, 第 1 日，第 2 日目には殆んど変化なく第 3 日目に $22.68 \mu \mathrm{g} / \mathrm{day}$ とやや減少，第 4 日 目には $13.73 \mu \mathrm{g} / \mathrm{day}$ となり投与前より約 $10 \mu \mathrm{g}$ の減少を見た。

A には第 1 例同様著明な変化は認められなかつた。

第 3 例は DOCA $5 \mathrm{mg}$ を 2 日間投与したものであるが投与後 NA は著明に減少し投与を中止方々再び

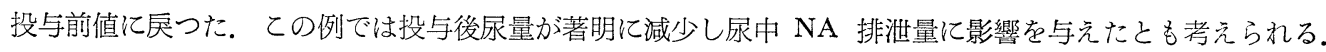
第 4 例は前例同様 DOCA $5 \mathrm{mg}$ を2 日連続投与したもので NA 排泄量はむしろ増加した例である。

以上総括すれば DOCA 負荷による尿中 NA は $10 \mathrm{mg} 4$ 日連続負荷によつても著しい変化のない例も あれば， $5 \mathrm{mg} 2$ 日投与により減少した例もあり一定の傾向は見られなかつた。なおての際 DOCA 投与後 の尿量減少による影響を一応考慮する必要があると思われる。

(2) 全剔後 (Table 11)

Table 11. Catecholamine output in urine after the administration of DOCA in bilateral adrenalectomized patients ( $\mu \mathrm{g} /$ day)

\begin{tabular}{c|c|c|c|c|c|c|c|c}
\hline Case & \multicolumn{2}{|c|}{1} & \multicolumn{2}{|c|}{2} & \multicolumn{2}{|c|}{3} & \multicolumn{2}{|c}{4} \\
\hline & A & N A & A & N A & A & N A & A & N A \\
\hline Bays & & & & & & & & \\
\hline Before & 0.17 & 15.89 & 0.47 & 20.31 & 1.41 & 14.18 & 0.82 & 14.47 \\
1 & 0.00 & 15.31 & 0.42 & 21.60 & 1.00 & 14.89 & 0.98 & 16.96 \\
2 & 0.61 & 16.48 & 0.24 & 21.31 & 0.04 & 14.22 & 0.56 & 18.56 \\
3 & 0.25 & 18.29 & 0.24 & 22.50 & 0.00 & 14.79 & 0.37 & 13.10 \\
4 & & & & & 0.34 & 16.52 & 0.76 & 14.07 \\
\hline
\end{tabular}

第 1 例 : DOGA $10 \mathrm{mg}$ を 3 日連続投与した所尿中 NA は投与前 $15.89 \mu \mathrm{g} / \mathrm{day}$, 第 2 日 $16.48 \mu \mathrm{g} / \mathrm{day}$ ，第 3 日 $18.29 \mu \mathrm{g} / \mathrm{day}$ でやや増加の傾向はあるが著明な変動は見られなかつた。 $\mathrm{A} も$ 同様変動なく減少したま まである。

第 2 例 : DOCA $10 \mathrm{mg}$ を 5 日連続投与し第 3 日目，4 日目， 5 日目に NA を測定したものである．投与 前 $20.31 \mu \mathrm{g} / \mathrm{day}$, 第 3 日目 $21.60 \mu \mathrm{g} / \mathrm{day}$, 第 4 日目 $21.31 \mu \mathrm{g} / \mathrm{day}$, 第 5 日目 $22.50 \mu \mathrm{g} / \mathrm{day}$ で NA の著明な增 減は見られなかつた。 A 同様変動はなかつた。

第 3 例 : DOGA 10mg を 3 日連続投与したが NA 及びA排渵量には影響は見られなかつた。

第 4 例 : DOCA $5 \mathrm{mg}$ を 3 日連続投与した所第 1 日目 $16.96 \mu \mathrm{g} / \mathrm{day}$, 第 2 日目 $18.56 \mu \mathrm{g} / \mathrm{day}$ となり投与前 より僅に増加し減少傾向は見られなかつた。

以上何れも NA は殆んど変化がないかむしろ僅かながら増加の傾向が見られ Cortisone 投与時の如く減 少傾向はなかつた．全剔後の維持 Steroid を Cortisone から Dexamethasone に10日切り換え，その後再 び Cortisone にて維持し尿中 NA を測定して見た. 测定結果は Fig. 10 の如くで Cortisone 維持で NA 排淮量 $32.65 \mu \mathrm{g} /$ day, Dexamethasone 維持で $32.43 \mu \mathrm{g} / \mathrm{day}$, 再び Cortisone 維持に切り換えた10日後には $30.58 \mu \mathrm{g} / \mathrm{day}$ で殆んど同様の值を示した．Cortisone には糖質作用の他住霆解質作用をも有しており，一方 Dexamethasone には殆んど電解質作用がないと云われている.

全剔後の維持に両者を使用しその尿中 NA 排泄量を比較した場合何ら有意の差が見られなかつた事，又 第 40 巻 第 10 号 
DOCA 投与では Cortisone 投与時程 NA の変動が見られなかつた事から主として Glucocorticoid と NA との間に関聯性があるものと考えられる.

\section{第 4 節 全剔前後の血圧変動と Catecholamine}

副腎髄質ホルモンとしての NA 及びA，皮質ホルモンとしての Glucocorticoid， Mineralocorticoid は 血圧調節に重要な Factor と考えられている。にれ故副腎全剔後の血圧変動が如何なる形で起るかを観察し て見た。

術前皮質ホルモンを投与しない患者の副㛑全剔術術中の血圧変動は Fig.11 の如くである. 即ち左副腎剔 出後右側副腎からのホルモン分泌が:存続するにも拘らず速かに血圧が下降する。乙の時 Hydrocortisone $100 \mathrm{mg}$ を静注すると血圧は正常にまで恢復し，更に右側の剔除と共に再び血圧が下降するが，同様：Hydrocortisone の投与により血圧は上昇して来る。乙の様な術前無処置例では術中血圧は著明に下降し稀にはシ ツョクに陥るものがあり皮質ホルモンの投与が絶対となる。しかし必ずしも Pressor amine (NA) は必 要としない. 術前から術中に Hydrocortisone $200 \mathrm{mg}$ 前後を投与した例では術中血圧変動は Fig.12 の如 く, 左及び右副腎剔出後にも血圧は非常に安定し血圧降下は見られない. それ故教室では全剔術術中の副腎

Fig. 10. Comparison between cortison and dexamethasone in their effects on urinary catecholamine output in bilateral adrenalectomized paitent

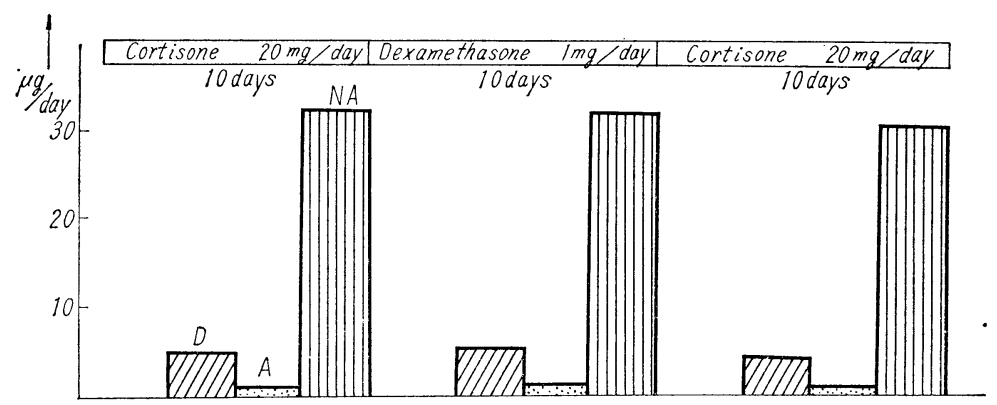

Fig. 11. Ghanges in blood pressure during operation Case 1, M.T. 40yrs F

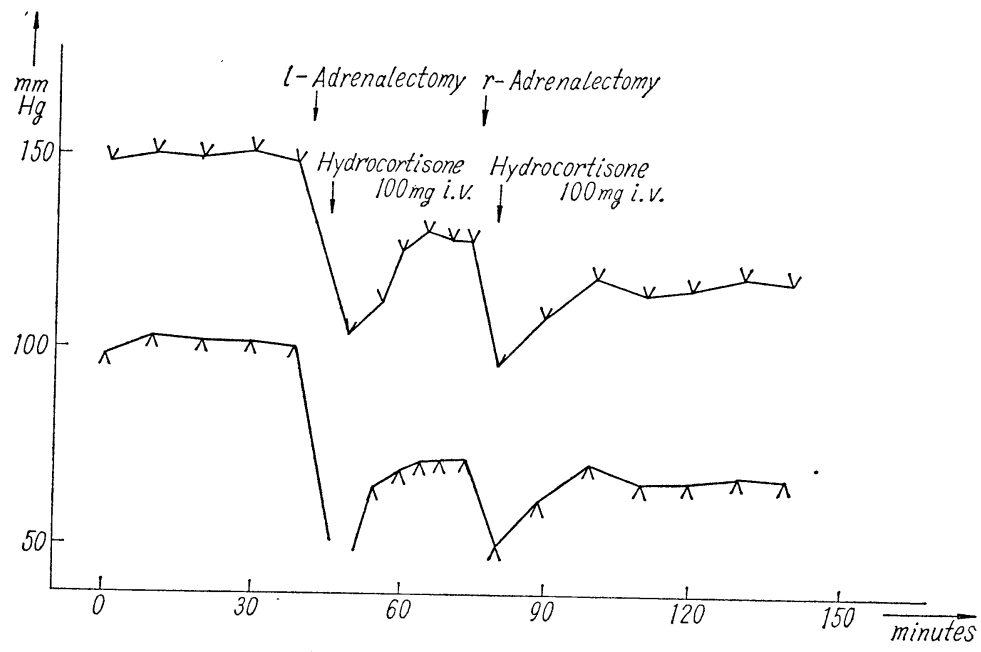


Fig. 12. Changes in blood pressure during operation Case 2, S.O. $45 \mathrm{yrs}$ F

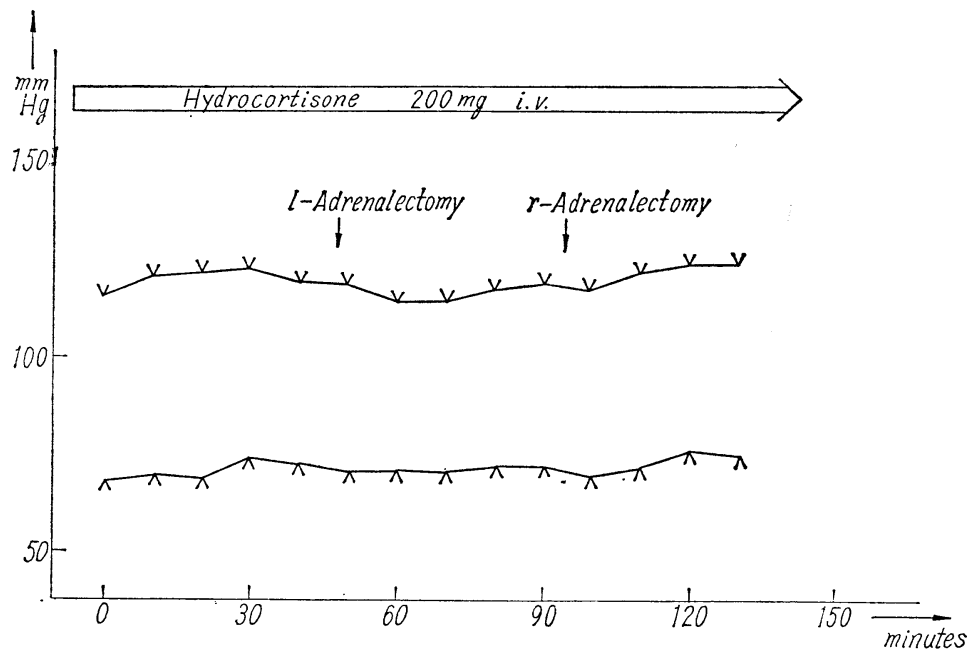

Fig. 13. Changes in blood pressure during operation Case 3, K.K. 58yrs F

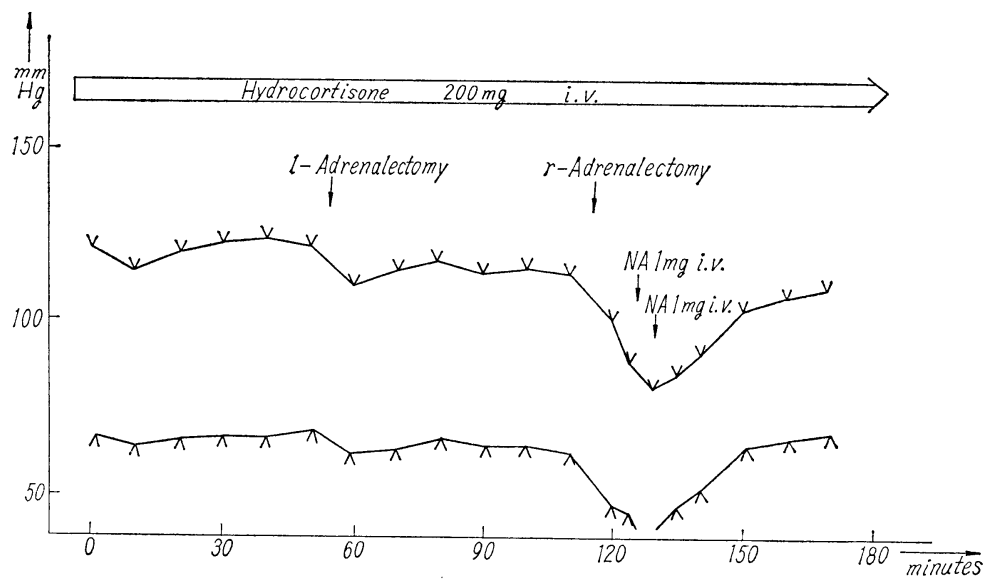

不全による血圧降下を予防する為すべて術前より Hydrocortisone を投与している.

しかしながら中には Fig. 13 の如く Hydrocortisone を投与してあるにも拘わらず副腎剔出後血圧は下 降し NA を投与しなければならぬ場合がある。

この様に Steroid Hormone の他に NA を併用しないと血圧を正常に維持し得ない症例は24例中 9 例で あつた. しかしての中には比較的重症なる例，手術時間の延長した例があり必ずしも鮪質ホルモンに依存性 が高かつた為とは考えられない，術後24時間から36時間頃まではなお血圧は不安定であるが，術後 4 日以後 には Fig. 14 の如く適当な Steroid Hormone の投与により血圧は安定した. 術後48時間までに血圧維持 の目的で NA の投与を必要とした例は24例中僅に 1 例（術中に必要とした 9 例中の 1 例）に過ぎず，又48 時間以後には全く無く，全剔患者の術後維持に Catecholamine を必要としない事が解つた。 
Fig. 14. Changes in blood pressure after bilateral adrenalectomy

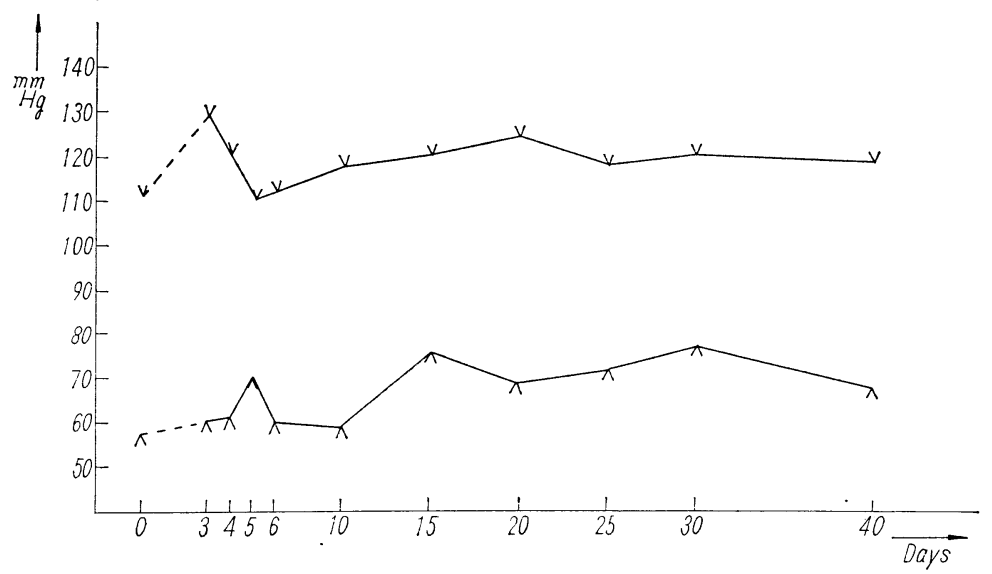

Fig. 15. Changes in blood pressure after the withdrawal of replacement therapy in bilateral adrenalectomized patients

Case 1

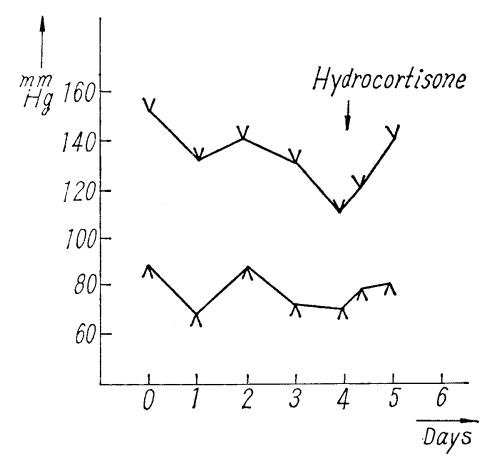

case 2

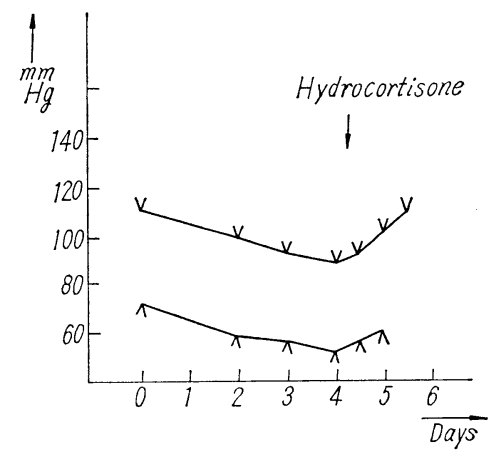

Fig. 16. Changes in blood pressure after the administration of noradrenaline and adrenaline before bilateral adrenalectomy
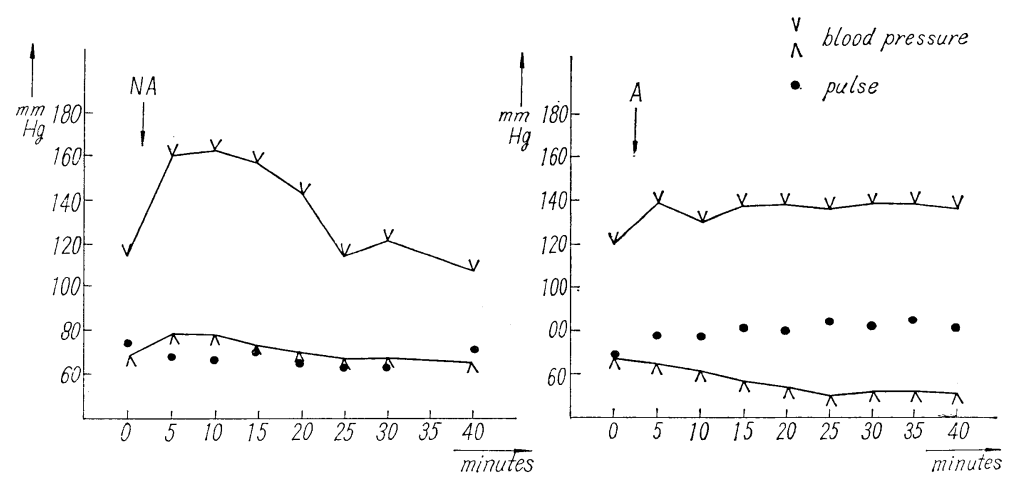
Fig. 17. Changes in blood pressure after the administration of noradrenaline and adrenaline at 2.5 months after bilateral adrenalectomy
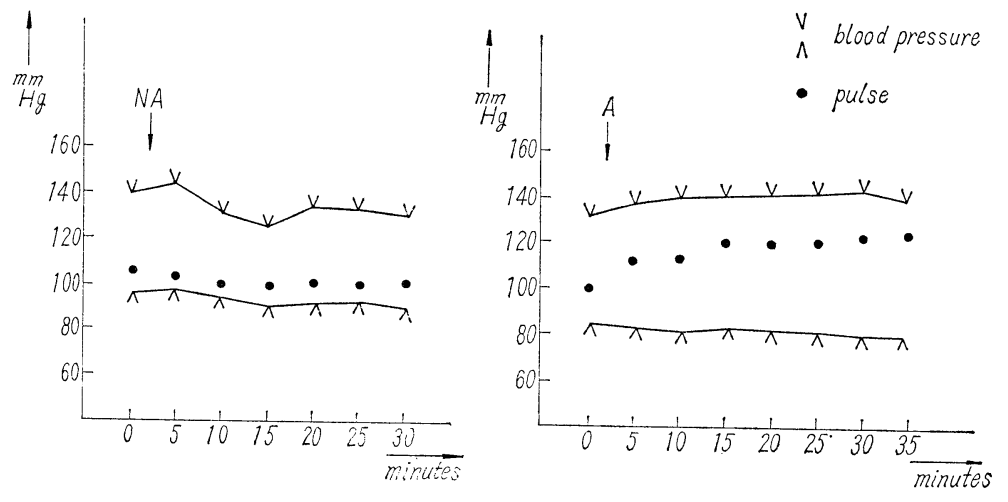

Fig. 18. Changes in blood pressure after the administration of noradrenaline and adrenaline at 24 months after bilateral adrenalectomy
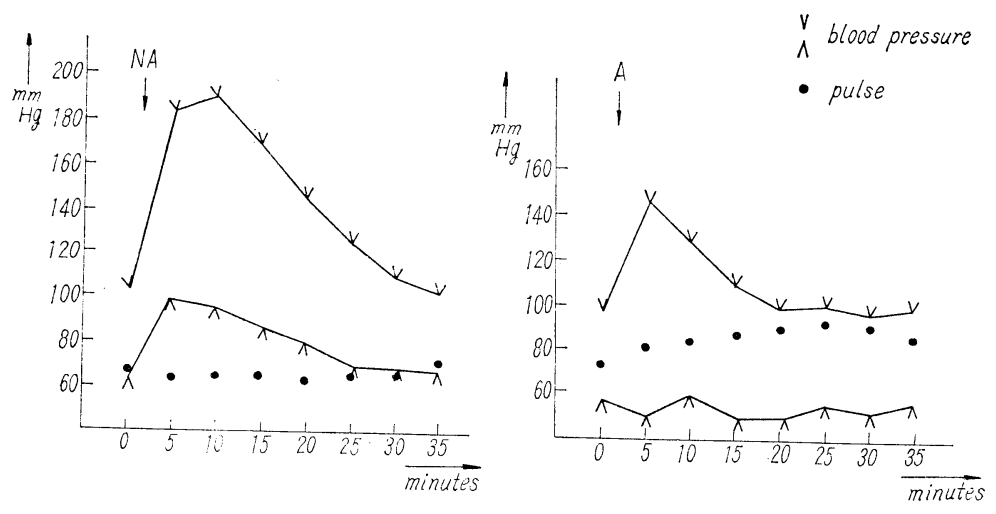

術後30日後，60日後の尿中 NA 排泄量の多い時期に特に血圧が上昇する様な傾向はなく血圧と NA 排泄 量とは必ずしも相関関係にない様に考えられた. なお Steroid 維持を中止する時には Fig. 15 の如く多く の場合中止 2 日にして種々の全身症状（全身倦急，頭重感，吐気，冷汗等）と共に血圧は著明に下降し始め る。しかし Cortisone を投与する事により速かにかかる自覚症状が消失，血圧は上昇して中止前の状態に戾 つた，ての際 NA 単独投与では血圧上昇は全く見られないか，あつても極めて弱く Glucocorticoid 在併 用して始めて強い上昇が見られる事は注目に值する。

即ち生体内 Catecholamine の態度は主として Steroid Hormone によつて決定される様に思われた。

\section{第 5 節 全剔患者の A，NA に対する感受性}

最近高血圧症の Catecholamine に対する感受性の問題が議論されているが全剔後尿中 NA 排泄量が増加 するにもかかわらず血圧上昇がそれに伴つて起らない事実から NA に対する感受性の低下が予想され，A 及び NA に対する全剔患者の反応を検討して見た. NA $0.5 \mathrm{mg} ， \mathrm{~A} 0.5 \mathrm{mg}$ の皮下注射を行い 5 分間隔で血 圧，脈その他の一般状態を観察した。 


\section{(1) 全剔前}

i） NA Test：Fig. 16 の如く負荷前収縮期圧112，拡張期圧70であつたものが5 分後は既に収縮期圧 162, 10分後には 164 と最高になり血圧上昇は約 25 分間にわたつて観察され NA に充分反応した．なお搪張期圧及 び脈膊数には殆んど変化が見られなかつた。

ii) A Test : NA 投与時にくらべて上昇度は低いが上昇持続時間は延長した。

(2) 全剔後 2 ケ月半

1）NA Test：Fig. 17 の如く投与前収縮期圧140から 5 分後に於ても144と僅かな血圧上昇あるのるで10 分後には130となり負荷前值より低くなつた．抁張期圧も同様殆んど変化が㒻られなかつた。

ii) A Test：殆んど血圧上昇は見られなかつた。なおての例は尿中 NA 排泄量が増加している時期にあ たりとの時期に殆んど NA に反応していない点は注目に值する。

(3) 全剔後24ケ月

1）NA Test：Fig. 18 の如く 5 分後収縮期圧 $188 ， 10$ 分後 192 となり負荷前より約 90 の昇があり全剔前 と同様著明に NA に反応した。 血圧上昇時間も大体 25 分から 30 分で全剔前と同様の pattern を取つた。

ii) A Test : 投与後血圧上昇が著明でやはり全剔前と同様A 強く反応している.

以上の結果より全剔後 2 ケ月半には負荷した NA に反応しないで血圧は殆んど上昇せず NA に対する感 受性が低下した事を示し，全剔後24ヶ月には全剔前と同様の経過を取つて著明な血圧上昇が起り感受性が正 常に戾つた事を意味している.

又Aに対する反応は全剔後 2ヶ月半には僅な低下が見られたが NA に対方る程著明でなかつた。 以上総 括すれば全剔直後 NA に対する感受性の低下が一時的に起り日数の経過と共にやがて感受性が徐々に正常 に戻つて来るものと考えられる。

\section{第 4 章 総括及び考按}

副腎全剔後の Catecholamine の動態を追求した報告は少く臨床実験では Euler ${ }^{17)}$ ，及び Schaepdryver ${ }^{40)}$, 動物実験では Leduc ${ }^{18)}$ 等の報告がある.

Euler ${ }^{17)}$ は1953年両側副腎を剔出した乳癌，高血圧，前立腺癌患者の尿中 Catecholamine を Bioassay 亿 より測定し，Aは全剔後減少，NA は不变かしばしば上昇する傾向がある事を報告している。筆者の成績で は尿中 $\mathrm{A}$ 排湛量は全剔後全例飞減少が見られ，術前の $1 / 3$ から少い例では $1 / 5$ 亿なつておりしかも数ヶ月 後更に 3 年後に測定した例でも減少したままである.

1946年 Euler ${ }^{19)}$ は adrenergic nerve より分泌されるのは主として NA である事を報告しているが，更 亿全剔患者の体位を傾斜させた時尿中 NA が増加しAの增加仙殆んどない事を見ておら ${ }^{20)}$, 又 Sundin $^{21)}$ は この際 gangion blocking agent をあらかじめ投与しておくと NA の分汹增加が起らない事を報告してい る. 又 Leduc ${ }^{22)}$ は全剔 rat 亿寒冷刺㦸を与えた時 NA のみの增加を見ており, Dunner ${ }^{23)}$ は Insuline 低 血梼時の副婜静脈血を直接分析し低血糖時の分泌增加はAに限られる事を見ており，Aは主として副腎䯣質 に由来し NA は㵦質よりもむしろ交感神経に由来すると考えられ，全剔後 $\mathrm{A}$ 排泄量が直ちに減少する事方か 理解される.

しかしAの排泄量が副腎全剔後決して0にならいのは副腎髄質以外に由来するAの存在が考学られる。 Armin，Grani ${ }^{24)}$ や Eulerら ${ }^{25)}$ は全剔患者に Insuline を投与する時，正常人よりは少いが僅なA排渵量の

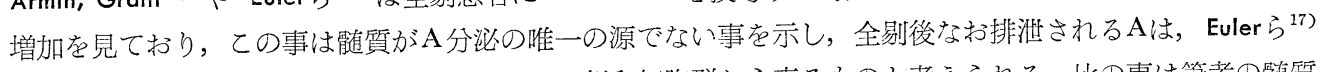
の云う所の髄質以外の他の器管にあるクローム親和細胞群から来るものと考えられる，比の事は筆者の踓質 剔除例で，Aのみが術後強く減少し又排泄量が亿ならなかつた事実からも理解される。

一方 NA は全剔後A とは逆に増加の傾向にあり，1 ケ月後に測定した例では術前の約 2 倍前後の増加が 
見られ，3ヶ月後においてもなお 3 倍から 4 倍, 多いものでは10倍近くも高值を示した. 又Aと NA の比

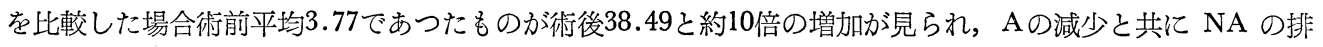
泄量増加のためにかかる高值を示したものと考光られる。

葡質剔除例と比較する時, 術後の NA 最高值が全剔例より低值である事や，1 ケ月後には既に術前値に戻 つている事など全剔後かなり長期にわたりしかも高値を持続する事実と異なり, 単に手術の stress やAの分 泌减少を代償するために一過性に NA の分泌充進が起るとは考觉られない.

髄質剔除例と全剔例とを比較した時，皮質ホルモン供給の有無が原因とも考光られるのである.

皮質ホルモンと Catecholamine との関係について田坂ら ${ }^{11)}$ は発熱時の尿中A，NA と 17 Ketosteroid とを測定し両者に相関関係は明らかでないと報告しているが横田, 德久等 ${ }^{26)}$ は体温上昇期に A, NA と共に皮 質ホルモンの増加を見ており，Halme等27) も手術前後で 17KS, 17-OHCS と Catecholamine とが相関聯 した動きがあるとし, 又 Frankson ${ }^{10)}$ は手術時の Stress により cortical activity のみならず adrenomedullary activity や adrenergic nervous system の activity の増加が起る事を報告しており，皮質ホル モンと Catecholamine との間には何らかの関聯性が考光られる。

そてで Cortisone, DOCA, ACTH を投与して尿中 NA の変動を検討した所, 全剔後 Cortisone 負荷に より尿中 NA 排泄量は著明に減少し, しかも NA 排泄量の多い時期程 Cortisone の影響か強くあらわれ る様に思われた. 又 ACTH 負荷では影響がなく, DOCA 負荷でも著明な変化が起らず Luft等 ${ }^{28)}$ の正常 人に対する報告と一致した. 又 Cortisone 維持でも Dexamethasone 維持でも NA 排泄量には差異がなく NA は Glucocorticoid にのみ影響されしかも両者の間に逆の相関関係がある様に思われた。

Selye の modern adaptation theory そ於ける alarm reaction では hypothalamus の刺㦸により先ず adrenal medullary hormone の分泌が起り ACTH 分泌を促進し二次的に adrenal cortical hormone $の$ 分泌増加か起るとしており ${ }^{29}$ ，実験的に Moor ${ }^{30)}$ や Pickford等 ${ }^{31)}$ はA，NA を静注するとき副腎皮質ホルモ ンの分泌が高まると報告し, 又 Elmadjian ${ }^{32)}$ や Euler等 ${ }^{33}$ は逆に ACTH を投与して尿中 Catecholamine の 減少を見ており，Catecholamine が ACTH の分泌を促進し逆に ACTH が Catecholamihe の分泌を阻 止する作用がある事を意味している。

Leduc ${ }^{22)}$ は全剔 rat に cold stress を加えた場合例へ適当なるSteroid で維持しても ganglionic blockade で NA の分泌を抑制すれば stress にたえ得ない事を見ており， stress に対する反応に NA は欠くべから ざる重要な Factor であるとしている.

上記の如く皮質ホルモンと髄質ホルモンとの間に，又 れ，副腎皮質の余備能を欠く全剔患者の stress に対する reaction として Catecholamine の分泌が正常よ り強く起るものと考えられる。

血圧の調節機構に Catecholamine が関与している事は疑いのない事実であるが近来高血圧症の病因の1つ として Aldosterone 系及び副腎皮質系と共に注目されるに致つた。しかしながら必ずしも高血圧とてれら Hormone との間には相関関係があるとは云えず，前川が云える如く高血圧の成因に対して内分泌系は必要 条件ではあるが決して充分な条件でない.

全剔後 NA の分泌充進があるにもかかわらず血圧は決して上昇しない事実からもとの事は理解される. 前川 ${ }^{34)}$ は内分泌系の血圧調節機構として, 低食塩食下の高血圧患者は Naによる昇圧手段を奪われるため 先ず第一に Aldosterone 系を動員して上昇血圧を維持しての機構で代償不全があれば第二次的に Catecholamine 系が動員されるとした。して見れば副腎全剔後の血圧降下を Catecholamine のみにより代償せん がために NA の分泌充進が起るとも考光られる。

他方今一つ NA 亿対する感受性の問題がある。 Rothman ${ }^{35)}$ は脳性高血圧は交感神経系の over active の ため，腎性高血圧は末梢血管の交感神経緊張に対する感受性の増大によるとし，Duff は悪性高血圧では良 性高血圧に比して 3 倍も感受性がえ進しているのを見ている. 又 Greisman ${ }^{36)}$ も同様本態性高血圧患者にA， NA に対する hyperreactivity がある事を報告, 鳥飼も同様の報告をしている。一方 Fowler ${ }^{37)}$ は副腎不全 
の動物には Pressor agent に対する反応を欠いていると述べ，又 Ramey等 ${ }^{38)}$ は全剔犬では NA に対する 感受性が低下し従つて NA に対する反応が弱く正常なる血圧上昇は起らないが Glucocorticoid (Mineralocorticoid では不変) 投与により回復する事を報告, Fritz ${ }^{39)}$ も同様全剔動物の NA に対する感受性の低下 が Glucocorticoid の投与により回復するとしている、筆者も長期間 Cortisone 服用のため副腎不全を起し た患者に NA 投与による血圧上昇反応が全く無く，A投与により shock を起した例を経験しており又両側 性の巨大褐色細胞腫の患者で一方の腫瘍剔出後, 片側になお巨大な腫瘍が残つており正常以上に多量のCatecholamine の分泌があるにもかかわらず血圧降下が著しく，血圧維持に多量の NA を術後しばらく必要と した例を経験しているが NA に対する感受性の問題がてれを或る程度理解させてくれる．そこで全剔前後 の NA に対する感受性を検討した結果全剔直後（NA 排泄量の多い時期）には NA に対する血圧反応が 極めて弱い事実より，ての時期に一時的に感受性の低下が起り血圧調節に正常条件下の最少必要量以上の NA を必要とし従つて NA の分泌元進が起つたものと考えられ, 又 Cortisone 投与により尿中 NA が減 少する事実は感受性が回復する為と考光れる。全剔後 2 年経過した例ではNA に対する反応は敏感で全 剔前と同様の血圧上昇が見られるが,てれはNA に対する感受性が正常に戻つて来たものと見てよく, 又比 の時期には尿中 NA も全剔前值に減少している. Leduc ${ }^{18)}$ は全剔 rat そ cold stress を与えた際尿中 NA の排泄量が急に上昇し, 更に寒冷下に放置しておく時 NA 排泄量が徐々に減少していくのを観察してれは NA に対する感受性が正常に戾るためとしているが，乙れと同様に全剔後一時 NA に対する感受性の低下 が起り血圧維持のため正常以上に NA の需要が高まり, 従つて NA 分泌量が増加し, やがて感受性が全剔 前の正常な状態に戻るため NA 分泌量も正常值近くに回復するものと考えられる.

\section{第 5 章 結 論}

副腎全剔前後の尿中 Catecholamine を佐野氏法にて測定し, 又 Cortisone, ACTH, DOCA 等の負荷に よる尿中 Catecholamine の変動を検討, 更に髄質剔除例と比較して次の如き結果を得た.

(1) 副腎全剔後尿中 A 排泄量は著明に減少し数ケ月後更に 3 年後に於ても減少したままで増加は見られず， 又排泄量が決して0にはならなかつた。乙れは髄質以外に由来する分泌と考えられる。

（2） NA は全剔後増加の傾向があり，1 ケ月後に約 2 倍， 3 ケ月後に於てもなお 3 倍から 4 倍の增加が見 られた. しかし増加せる NA は6〜12ケ月後には再び術前のレベルにまで減少した.

（3）髄質剔除例ではAはやはり著明に減少し増加の傾向はなく，NA は一時増加するが約 1 ケ月後には正 常值に戾つた.

（4）全剔後増加せる尿中 NA 排泄量は Cortisone 投与により減少し，DOCA 負荷では著明な変動は見 られず主として Glucocorticoid に NA は影響される様に思われた。

ACTH 負荷では全剔前には NA 排泄量の減少傾向が見られたが全剔後では不変であつた.

（5）全剔術直後には血圧は不安定であつたが 4 日以後には安定となり，且，尿中 NA 排泄量の多い時期 に特に血圧が上昇する傾向が見られなかつた。

(6) 全剔術術中に血圧維持のため NA を必要とした例は24例中 9 例のみで又術後48時間以後に NA を必 要とした例は無く，全剔患者の術後維持に Catecholamine を必要としない事を知つた.

（7）全剔患者の維持 Steroid を中止する時起る著明な血圧下降は Cortisone 投与により速かに恢復するが NA 単独投与では殆んど血圧は上昇せず Glucocorticoid を併用して始めて強い血圧上昇が見られ，生体内 Catecholamine の態度は Steroid Hormone によつて決定される様に思われた。

（8）NA に対する感受性テストで全剔後早期には感受性が低い傾向にあるが，その後感受性が正常に戻る 事が解つた．乙れは全剔後にNA の分泌元進が起る原因の一つと考えられる。

（本論文の要旨は第35回日本内分泌学会総会に扔いて発表した）

稿を終るにあたり終始御留切な御指導並びに御校閲を賜つた恩師今永一教授に深く感謝の意を表すると共 
亿直接御指導御助言をいただいた永井良治助教授並びに仙石光彦，吉田穰両博士に厚く御礼申し上げます。

\section{文献}

1) GURIN, S., DELlUVA, A.M. : J. Biol. Chem., $170: 545$, (1947).

2) BLASGHKO, H. :

Brit. med. Bull., 13 : 162, (1957).

3) ARMSTRONG et al : J. Biol. Chem., $226: 255$, (1957).

4) PEKKARINEN, A. : Acta physiol. scand., 16, Supple. 54, (1948).

5) LUND, A. : Acta pharmacol., $6: 137$, (1950).

6) WEIL MARHERBE, H. and A.D. BONE : Lancet, $264: 974$, (1953). 7) EULER, U.S.V. and FLODING, I. : Acta physiol. scand., 33, Supple. 118, (1955). 8) KIRSGHNER, N. and GOODALL, M. : J. Biol. Chem., $226: 207$, (1957). 9) ENGEL, A. and EULER, U.S.V. : Lancet, $2: 387,(1950) . \quad 10)$ G. FRANKSSON, M.D., C.A. GEMZELL, M.D. and U.S.V. EULER, M.D. : J. Clin. Endo. and Metab., 14:608, (1954). 11) 田坂定孝, 吉植庄平, 山田律爾：綜合臨床，8 (3)，149，(1959)。

12) U.S.V. EULER and S. HELLNER : Acta physiol. scand., 26 : 183, (1952). 13) A.M. LANSING and J.A.F. Stevenson : Am. J. Physiol., 193 (2) : 289, (1958). 14) U.S.V. EULER : Scand. J. Clin. and Lab.Invest., 4 : 254, (1952). 15) U.S.V. EULER : Noradrenaline, 248, (1956). 16) 佐野 馨, 蒲生達三, 橋 本裕一：日内分泌誌，35 (1) : 86，(1959)。 17) U.S.V. EULER, C. FRANKSSON and J. HELLSTRÖM : Acta physiol. scand., $31: 1$, (1954). 18 J) J. LEDUG : Acta physiol. scand., $51: 94,(1961) . \quad 19)$ U.S.V. EULER : Acta physiol. scand., $12: 73,(1946) . \quad 20)$ U.S.V. EULER and C. FRANKSSON : Acta physiol. scand., $38: 275$, (1957). 21) SUNDIN, T. : Acta physiol. scand., Supple. 336, (1958). $\quad 22)$ J. Leduc : Acta physiol. scand., Supple. 183, Vol 53, 50, (1961). 23 ) H. DUNER : Acta physiol. scand., $32: 62$, (1954). ARMIN and R.T. GRANT : J. physiol., $149: 228$, (1959). $\quad 25)$ U.S.V. EULER and R. LUFT : Acta Endocrinol., 38 : 441, (1961). 26) 徳久梯次郎 : 日内分泌誌, $45: 879,(1956)$. 27) HALME, A. et al. : Acta Endocrinol. Supple. 32 : 1, (1957). 28) R. LUFT, and U.S.V. EULER : Metabolism,1 : 179, (1952). 29) O. FORSSMAN, G. HANSSON, and G.G. JENSEN : Acta medica scand., Vol CXLII, fasc. VI, 442, (1952). $\quad 30)$ P. De.MOOR, E. MENLEPAS, M. HINNEKENS. and A. HENDRIKX : Acta Endocrin., $38: 262$, (1961). $\quad 31)$ M. PICKFORD and M. VOGT : J. Physiol., $112: 133$, (1951). $\quad 32$ ) F.ELMADJIAN et al : J. Glin. Endo. Metab., $16: 222$, (1956). $\quad 33$ ) U.S.V. EULER and R. LUFT : Acta Endocrinol., $3: 323$, (1949).

35) SOL. ROTHMAN and DOUGLAS R. DRURY : Am. J. Physiol., 188 : 371, (1957). 36) SHELDON E. GREISMAN : J. Clin. Invest., $31: 782$, (1952). $\quad 37)$ J.L.A.FOWLER and R.A. CLEGHORN : Am. J. Physiol., 137 : 371, (1942). 38) E.R. RAMEY, M.S. GOLDSTEIN and R. LEVINE : Am. J. Physiol., 165 : 450, (1951). 39) I. FRITZ and. R. LEVINE : Am. J. Physiol., $165: 456$, (1951). 40) AF De. SCHAEPDRYVER and W. SMETS : Arch. int. Pharma. et de therap., No. 3 4, 467, (1961). 